sume that they are in the best position to detect disloyalty, and that they will be alert to the danger of seditious persons in the schools. It is more for the regents, the courts, and the legislatures, with whom the ultimate safeguarding of liberty rests, to guard against the schools becoming forums for partisan political maneuvering.

If it is the common report that our schools are infiltrated with "subversive persons" it is also the common report that the schools face a crisis in giving Americans the education they must have. If they are to meet that crisis, not only the physical problems of buildings and finance must be solved, but the problem of personnel must be conquered. A pattern of constant testing of teachers for political innocuousness is hardly likely to draw the sort of teacher who would imbue children with a vigorous love of justice, democratic principles, or country.

Socrates, answering the common report that he was a subversive and a corrupter of youth, said of one of his accusers: "He says that I am a doer of evil and corrupt the youth, but I say to men of Athens, that Meletus is a doer of evil in that he pretends to be in earnest when he is only in jest and is so eager to bring men to trial from a pretended zeal and interest in matters in which he really never had the smallest interest." 58

\title{
RAILROAD LABOR DISPUTES AND THE NATIONAL RAILROAD ADJUSTMENT BOARD
}

In two cases decided in the spring of $1950,{ }^{x}$ the Supreme Court, by a new construction of the 1934 amendments to the Railway Labor Act (RLA), ${ }^{2}$ conferred upon the National Railroad Adjustment Board (NRAB) exclusive primary jurisdiction of disputes involving the interpretation and application of collective-bargaining agreements in the railroad industry. The effect of these decisions is to deny parties to the disputes initial resort to state and federal courts, and to limit judicial consideration of these controversies mainly to suits in federal courts for the enforcement of NRAB awards. This holding invites a closer scrutiny of the NRAB's internal operation and its relation to the system of collective bargaining in the railroad industry.

The courts have come to regard collective-bargaining agreements as contracts which may be enforced by any employee who is covered by them, ${ }^{3}$ regard-

${ }^{8}$ Plato, Apology, Works of Plato 67 (Mod. Lib. ed., r928).

¿ Slocum v. Delaware, L. \& W. R. Co., 339 U.S. 239 (I950); Order of Ry. Conductors v. Southern R. Co., 339 U.S. 255 (r950).

${ }^{4} 44$ Stat. 577 (I926), as amended, 48 Stat. I185 (I934), 45 U.S.C.A. $\$$ I5I (I943).

3 An early difficulty with the suit to enforce a collective-bargaining agreement as a contract was found by some courts in the lack of consideration from the individual employee who 
less of union affiliation. ${ }^{4}$ They freely allow complaints by individual employees, ${ }^{5}$ and where other employees would be affected by a judgment sought against an employer, the court will not only permit, but insist on, their being notified and given an opportunity to be heard. ${ }^{6}$ The courts have not limited their jurisdiction to disputes between management and employees. The rights"created by bargaining agreements have also been protected against interference by other employees, 7 the bargaining agent itself, ${ }^{8}$ and other unions. ${ }^{9}$ Protection has even been given to an employment status not covered by an agreement, but which would have been continued by the employer but for the outside interference complained of. ${ }^{\text {xo }}$ Although the availability of judicial relief is doubtful in some types of disputes, ${ }^{\text {II }}$ judicial sanctions have been invoked to maintain every

brings the suit. He was not a party to the agreement and did not agree to serve under it. Hudson v. Cincinnati, N. O. \& T. P. Ry. Co., I52 Ky. 7II, I54 S.W. 47 (I9I3); West v. Baltimore \& Ohio R. Co., ro3 W.Va. 417, I37 S.E. 654 (I927); Burnetta v. Marceline Coal Co., I80 Mo. 24I, 79 S.W. 136 (Ig04). Also see Gary v. Central of Georgia R. Co., 37 Ga. App. 744, I4I S.E. 8I9 ( $x_{928)}$, which permitted suit where the plaintiff's contract of employment had incorporated the collective provision sued on. Some courts could see their way to enforcing wage and working condition provisions in the agreement, but balked at those restricting the employer's right to discharge at will because the employee was always free to quit. Louisville \& N. R. Co. v. Bryant, 263 Ky. 578, 92 S.W. 2d 749 ( 1936 ). In Gulla v. Barton, 164 App. Div. 293, $x 49$ N.X. Supp. 952 (IgI4), the agreement was treated as a benefit to which the plaintiff employee was entitled by virtue of having paid dues to the union which made it. It was enforced as a contract to which the plaintiff was a real, though not a named party. As now conceived, the agreement is not in itself a contract, but rather an offer, which becomes a contract when an individual accepts it by taking employment which is covered by the agreement. See Illinois Central R. Co. v. Moore, II2 F. 2 d 959 (C.A. 5th, I940).

4 Union members permitted to sue: Gulla v. Barton, I64 App. Div. 293, I49 N.Y. Supp. 952 (I9r4); Blum \& Co. v. Landau, 23 Ohio App. 426, I55 N.E. I54 (r926); Piercy v. Louisville \& N. Ry. Co., I98 Ky. 477, 248 S.W. 1042 (1923); Cross Mountain Coal Co. v. Ault, I57 Tenn. 46r, 9 S.W. 2d 692 (rg28). Nonunion employees allowed to sue on a union agreement: Gregg v. Starks, 188 Ky. 834, 224 S.W. 459 (I920); Yazoo \& M. V. R. Co. v. Sideboard, I6I Miss. 4, I33 So. 669 (I93I); Yazoo \& M. V. R. Co. v. Webb, 64 F. 2d 902 (C.A. 5th, I933). For a review of these and other early cases see Rentschler v. Missouri Pacific R. Co., x26 Neb. 493, 253 N.W. 694 (r934).

5 Cases cited note 4 supra.

${ }^{6}$ See note 74 infra.

'Stephenson v. New Orleans \& N. E. R. Co., 180 Miss. 147 , I77 So. 509 (1937); Long v. Van Osdale, 26 N.E. 2d 69 (Ind. App., I940).

${ }^{8}$ Piercy v. Louisville \& N. Ry. Co., I98 Ky. 477, 248 S.W. I042 (I923); Crowell v. Palmer, r34 Conn. 502, 58 A. 2d 729 (1948); Dooley v. Lehigh V. R. Co., I30 N.J. Eq. 75, 21 A. 2d 334 (194I); Capra v. Local Lodge No. 273, Io2 Colo. 63, 76 P. $2 \mathrm{~d} 738$ (1938); System Federation No. 9 I v. Reed, I8o F. 2d 99I (C.A. 6th, r950).

9 Randolph v. Missouri-K.-T. R. Co., 68 F. Supp. Ioo7 (Mo., I946), rev'd I64 F. 2d 4 (C.A. 8th, I947); Delaware, I. \& W. R. Co. v. Slocum, 299 N.Y. 496,87 N.E. 2 d 532 (I949), rev'd 339 U.S. 239 (1950); see Griffin v. Illinois Central R. Co., 88 F. Supp. $55^{2}$ (IIl., 1949).

ro Hunter v. Atchison, T. \& S. F. Ry. Co., I7x F. 2d 594 (C.A. 7th, r948).

II Especially the jurisdictional dispute. See text at note 85 infra; Hampton v. Thompson, I7I F. 2d 535 (C.A. 5th, I948). 
aspect of collective bargaining. ${ }^{22}$ In effect, the collective bargaining agreement is enforced as the law of the employment relationship. ${ }^{13}$

Collective bargaining in the railroad industry has received special treatment from Congress. ${ }^{14}$ In 1926 the RLA ${ }^{15}$ imposed on the carriers the duty to bargain collectively, and in 1934 Congress added criminal sanctions to this provision and set up machinery for election by each class or craft of its bargaining representative. ${ }^{16}$ The ${ }^{9} 934$ amendments also provided for the establishment of the NRAB,${ }^{17}$ to have jurisdiction over "disputes between an employee or group of employees and a carrier or carriers growing out of grievances or out of the interpretation or application of agreements concerning rates of pay, rules, or working conditions...." The disputes "may be referred by petition of the parties or by either party to the appropriate division of the Adjustment Board ..." [emphasis added], in the event that preliminary conferences held on company property do not result in an adjustment. ${ }^{18}$

12 E.g., cases cited notes 7, 8 and 9 supra; Virginian Ry. Co. v. System Federation No. 40, 300 U.S. 5 I5 (I937) (injunction requiring carrier to bargain with employees' elected representative); Brand v. Pennsylvania R. Co., 22 F. Supp. 569 (Pa., I938) (court has jurisdiction to enjoin award of system board of adjustment which was made without notice or hearing to plaintiffs); Brotherhood of Ry. Clerks v. Nashville, C. \& St. L. Ry. Co., 94 F. 2 d 97 (C.A. 6th, 1937) (upheld refusal of injunction to enforce Mediation Board certification of collective bargaining agent under RLA because not supported by evidence).

${ }^{13}$ This is a realistic view of the collective bargaining system as practiced in the railroad industry. Under the RLA the members of a craft or class (determined by the National Mediation Board) elect a bargaining representative to conduct negotiations with the carrier for a collective agreement. The whole class, including the minority which may have dissented from the choice of representative, is bound by this agreement, regardless of whether or not they are members of the chosen representative. Brisbin v. E. L. Oliver Lodge No. 335, I34 Neb. $5 \mathrm{I} 7$, 279 N.W. 277 (1938); Austin v. Southern Pacific Co., 50 Cal. App. 2d 292, I23 P. 2d 39 (I942). Employees may escape the agreement only by quitting, an alternative which has little attraction in view of the advantages of seniority already accrued and the difficulty of finding new employment in the industry especially after the age of forty. See Austin v. Southern Pacific R. Co., supra.

${ }^{14}$ Government intervention began with the creation of the Interstate Commerce Commission in 1877 (24 Stat. 379) and the first arbitration legislation in I888 (25 Stat. 50r). Activity was limited to development of arbitration and mediation techniques and occasional strike-breaking until World War I. After the war the Railroad Labor Board was established under the Transportation Act of $x 920$ ( $4 \mathrm{x}$ Stat. 469,470 ) to make rules and set wages, but it had no power to carry out any of its awards or mandates. It was replaced in 1926 by the Board of Mediation created by the RLA ( 44 Stat. 579), which had no rule-making powers, but merely provided a voluntary mediation and arbitration service. Adjustments under effective agreements were left to bipartisan boards to be created by private agreement between unions and carriers, although the Board of Mediation could be asked to decide deadlocked cases. This adjustment machinery proved unworkable, and amendments to the RLA in I934, 48 Stat. II85, 45 U.S.C.A. \& I5I (I943), established the NRAB as the mainspring of a new adjustment procedure and provided much needed sanctions against anti-union activities by the carriers. See Garrison, The National Railroad Adjustment Board-A Unique Administrative Agency, 46 Yale L.J. 567, 568-76 (I937); First Annual Report of the National Mediation Board 59 (I935).

${ }^{15} 44$ Stat. 579, as amended, 45 U.S.C.A. \& I5I (I943).

${ }^{16} \S 2,48$ Stat. $x x_{5}$ (1934), 45 U.S.C.A. $\& \mathrm{I}_{52}$ (1943).

${ }^{17}$ Ibid., at $\S 3$ and $\S 153$. $\quad{ }^{88}$ Ibid., at $\S 3$ First (i) and $\S I_{53}$ First (i). 
The state courts generally maintained that this provision did not deprive them of their pre-existing jurisdiction, ${ }^{19}$ and the view was shared by some federal courts with regard to both the state courts and federal diversity jurisdiction. ${ }^{20}$ However, the election of a forum, once made, was binding on the parties. ${ }^{2 x}$ If the forum was the NRAB, the narrow review provisions of the RLA provided the only means of getting into court, ${ }^{22}$ unless the NRAB refused to take the case. ${ }^{23}$

The concurrent jurisdiction view was apparently accepted by the Supreme Court in $\mathrm{I940}$, in the case of Moore v. Illinois Central R. Co. ${ }^{24}$ where an employee sued in a state court for damages for wrongful discharge; the case then being removed on the basis of diversity. The Court said that the administrative

I9 Explicit holding: Evans v. Louisville \& N. R. Co., I9I Ga. 395, I2 S.E. 2d 6II (1940); Watson v. Missouri-K.-T. R. Co., I73 S.W. 2d 357 (Tex. Civ. App., I943); Southern Ry. Co. v. Order of Ry. Conductors, 210 S.C. I2I, 4I S.E. 2d 774 (I947), rev'd 339 U.S. 255 (I950); Delaware, L. \& W. R. Co. v. Slocum, 299 N.Y. 496, 87 N.E. 2d 532 (r949), rev'd 339 U.S. 239 (I95). Treated case without comment: Dooley v. Lehigh Valley R. Co., r3o N.J. Eq. 75, 2 A. 2d 334 (I94I); Moore v. Yazoo \& M. V. R. Co., I76 Miss. 65, I66 So. 395 (1936); Capra v. Local Lodge No. 273, ro2 Colo. 63, 76 P. 2 d 738 (1938). Contra: State ex rel. St. Louis-S. F. Ry. Co. v. Russell, $35^{8}$ Mo. $1 \times 36$, 219 S.W. $2 d 340$ (r949); see Tharp v. Louisville \& N. R. Co., 307 Ky. 322, 210 S.W. 2d 954 (1948); Mansell v. Texas \& P. Ry. Co., 135 Tex. 3I, I37 S.W. 2d 997 (1940); cf. Wyatt v. Kansas City Southern Ry. Co., Ior S.W. 2 d ro82 (Tex. Civ. App., I937).

${ }^{20}$ Southern Ry. Co. v. Order of Ry. Conductors, 63 F. Supp. 306 (S.C., I945); Delaware, L. $\&$ W. R. Co. v. Slocum, 56 F. Supp. 634 (N.Y., I944); Adams v. New York, C. \& St. L. R. Co., I2I F. 2d 808 (C.A. 7th, I94 I); Swartz v. South Buffalo Ry. Co., 44 F. Supp. 447 (N.Y., 1942); Shipley v. Pittsburgh \& I. E. R. Co., 83 F. Supp. 722 (Pa., I949); Washington Terminal Co. v. Boswell, 124 F. 2d 235 (App. D.C., 194I). Contra: Hampton v. Thompson, 17I F. 2d 535 (C.A. 5th, I948); Missouri-K.-T. R. Co. v. Randolph, I64 F. 2d 4 (C.A. 8th, I947); McDermott v. New York Central R. Co., 32 F. Supp. 873 (N.Y., I940); United States ex rel. Deavers v. Missouri-K.-T. R. Co., x7 I F. 2d 96I (C.A. 5 th, x949); In re Central R. Co. of N.J. [O.R.C. v. Pitney], I45 F. 2d 35 I (C.A. 3d, r944); Illinois Central R. Co. v. Brotherhood of R.R. Trainmen, 83 F. Supp. $93^{\circ}$ (Ill., I949). Federal courts declined to accept nondiversity cases, stating that the cause of action arose out of the common law, not the RLA. Cases cited pro, supra; Malone v. Gardner, 62 F. 2d I5 (C.A. 4th, I932) (pre-NRAB); Lewis v. New York Central R. Co., I7 C.C.H. Lab. Cas. I65,425 (D.C. Ill., I949); Strawser v. Reading Co., 80 F. Supp. 455 (Pa., I948).

${ }^{2 x}$ Kelly v. Nashville, C. \& St. I. Ry., 75 F. Supp. 737 (Tenn., I948); Washington Terminal Co. v. Boswell, I24 F. 2 d 235 (App. D.C., I94I); Ramsey v. Chesapeake \& Ohio R. Co., 75 F. Supp. $74^{\circ}$ (Ohio, I948); Hicks v. Thompson, 207 S.W. 2 d I000 (Tex. Civ. App., I948); Austin v. Southern Pacific Co., 50 Cal. App. 2d 292, 123 P. 2d 39 (I942); see Watson v. MissouriK.-T. R. Co., I73 S.W. $2 d 357$ (Tex. Civ. App., I943).

2 Reynolds v. Denver \& R. G. W.R. Co., I74 F. 2 d 673 (C.A. roth, I949); Ramsey v. Chesapeake \& Ohio R. Co., 75 F. Supp. 740 (Ohio, I948); Berryman v. Pullman Co., 48 F. Supp. 542 (Mo., I942); Williams v. Atchison, T. \& S. F. Ry. Co., 356 Mo. 967, 204 S.W. 2d 693 (x947); Hecoz v. Pullman Co., 85 F. Supp. 34 (Wash., I949); Hargis v. Wabash R. Co., I63 F. 2d 608 (C.A. 7th, I947); see dissenting opinion, Elgin, J. \& E. R. Co. v. Burley, 325 U.S. 7 Ir, 749 (1945). But see Washington Terminal Co. v. Boswell, r24 F. 2d 235, 245 (App. D.C., I94I); Watson v. Missouri-K.-T. R. Co., I73 S.W. 2d 357, 362 (Tex. Civ. App., r943); opinion of Holly, J., in Hargis v. Wabash R. Co., supra at 6rr.

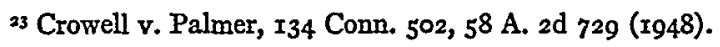

${ }^{24} 312$ U.S. 630 (1940). 
remedies provided by the RLA, even the requirement of conferences on company property, need not be exhausted before resort is made to the courts. A pronounced shift from the Moore case was evident in the Supreme Court's x944 decision, Order of Raikway Conductors v. Pitney, ${ }^{25}$ in which a bankruptcy court was confronted with a jurisdictional dispute between the plaintiff and the Brotherhood of Railroad Trainmen, each union maintaining that its own contract covered certain disputed jobs. The Supreme Court ruled that the bankruptcy court should not attempt to interpret the contracts itself, but should retain jurisdiction of the dispute until the parties had an opportunity to consult the NRAB for interpretation of the two agreements. It could then proceed to protect the rights so revealed. .

After this decision the state courts continued to dispose of cases in the field, ${ }^{26}$ but some federal courts instituted a policy of denying access to the federal courts prior to a decision by the NRAB. ${ }^{27}$ This mandatory primary jurisdiction of the NRAB has been further extended by the two recent cases of Slocum v. Delaware, L. $\&$ W. R. Co. ${ }^{28}$ and Order of Railway Conductors v. Southern Ry. Co. ${ }^{29}$ in which the Supreme Court sharply restricted the concurrent jurisdiction of both state and federal courts. Both cases involved the interpretation of agreements, and the Court was impressed with the desirability of having this done uniformly and expertly. It stated that this objective, which was the basis of the Pitney decision, "equally supports a denial of power in any court-state as well as federal-to invade the jurisdiction conferred on the Adjustment Board by the [RLA]." ${ }^{\circ 0}$ It should be noted that this jurisdiction is not limited to interpretations, but extends to all grievances and adjustments. ${ }^{3 x}$ Rather than overrule the Moore case,

${ }^{25} 326$ U.S. 56 I (I944).

${ }_{26}$ Delaware, I. \& W. R. Co. v. Slocum, 299 N.Y. 496, 87 N.E. 2d 532 (I949), rev'd 339 U.S. 239 (I95O); Southern Ry. Co. v. Order of Ry. Conductors, 2IO S.C. I2I, 4I S.E. 2d 774 (1947), rev'd 339 U.S. 255 (1950); Wooldridge v. Denver \& R. G. W. R. Co., Ir8 Colo. 25, I9I P. 2d 882 (I948); Coyle v. Erie R. Co., I42 N.J. Eq. 306, 59 A. 2d 8I7 (I948). Contra: State ex rel. St. Louis-S. F. Ry. Co. v. Russell, $35^{8}$ Mo. rr36, 219 S.W. 2d 340 (1949); see Tharp v. Louisville \& N. R. Co., 307 Ky. 322, 210 S.W. 2d 954 (I948).

${ }_{27}$ Hampton v. Thompson, I7I F. 2d 535 (C.A. 5th, I948); Missouri-K.-T. R. Co. v. Randolph, I64 F. 2d 4 (C.A. 8th, I947); United States ex rel. Deavers v. Missouri-K.-T. R: Co., I7I F. 2d 96r (C.A. 7 th, I949); Howard v. Thompson, 72 F. Supp. 695 (Mo., I947); Griffin v. Illinois Central R. Co., 88 F. Supp. $55^{2}$ (Ill., I949); Missouri-K.-T. R. Co. v. NRAB, I8 C.C.H. Lab. Cas. I65,8I4 (D.C. Ill., I950); United R.R. Workers v. Atchison, T. \& S. F. Ry. Co., 89 F. Supp. 666 (Ill., I950); see Starke v. New York, C. \& St. L. R. Co., I80 F. $2 d 569$ (C.A. 7 th, I950); Order of R.R. Telegraphers v. New Orleans, T. \& M. Ry. Co., I56 F. 2d I (C.A. 8th, I946). Contra: Randolph v. Missouri-K.-T. R. Co., 68 F. Supp. roo7 (Mo., I946), rev'd I64 F. 2d 4 (C.A. 8th, I947); System Federation No. 9r v. Reed, r8o F. 2d 99 I (C.A. 6th, 1950); Hughes v. Chicago, R. I. \& P. R. Co., I8 C.C.H. Lab. Cas. \65,882 (D.C. Okla., I950); see Delaware, I. \& W. R. Co. v. Slocum, 56 F. Supp. 634 (N.Y., I944); Southern Ry. Co. v. Order of Ry. Conductors, 63 F. Supp. 306 (S.C., I945).

$$
{ }^{28} 339 \text { U.S. } 239 \text { (1950). } \quad{ }^{29} 339 \text { U.S. } 255 \text { (r950). }
$$

${ }^{30}$ Slocum v. Delaware, L. \& W. R. Co., 339 U.S. 239, 244 (I950).

3x RLA, \& 3 First (i), 48 Stat. II85 (1934), 45 U.S.C.A. $\S$ I53 First (i) (I943), quoted in text at note 18 supra. 
the Court did recognize a common-law jurisdiction in the courts which would survive the present decision. But judicial relief in disputes under collective bargaining agreements has always been based on common-law grounds rather than on the RLA..$^{22}$ It can only be surmised that the Supreme Court intends to limit the surviving "common-law" jurisdiction to the exact facts in the Moore case, for otherwise the exception would be as broad as the rule. ${ }^{33}$ Unfortunately, the tribunal which has been given such increased importance by this ruling is unsatisfactory in many respects, and most of its decisions are immune from judicial review under the RLA.

\section{II}

The NRAB consists of four separate tribunals, each with jurisdiction over disputes involving members of certain crafts and classes specified in the RLA. ${ }^{34}$ Each tribunal, called a division, is composed of equal numbers of labor and carrier representatives, who are chosen and paid by the national railroad labor unions and the interstate railroads. ${ }^{35}$ In the event that a division splits evenly on a decision, a referee is brought in to vote with the division in making an award..$^{36}$ The interests of the board members, although generally opposed and balanced, make this government agency unique in both composition and operation, and is the source of most of its difficulties and disadvantages. ${ }^{37}$

32 Cases cited notes 19,20 supra.

33 As to the legal merit of this decision, see the forceful dissenting opinion of Justice Reed in the Slocum case, 339 U.S. 239, 245 (1950), quoted in part, note ro7 infra. The Court purported to distinguish the Moore case as an ordinary common-law action for damages, as opposed to suits for reinstatement, seniority rights, etc., which are not "common-law." Such a distinction forgets that although rights under collective bargaining agreements were expressly limited to damages in a few early cases-e.g., Hamilton v. Rouse, I78 App. Div. 8I, I65 N.Y. Supp. I73 (I9I7); Robinson v. Dahm, 94 N.Y. Misc. 729, I59 N.Y. Supp. Io53 (rgr6)-equitable relief has been frequently sought and given. E.g., Gregg v. Starks, I88 Ky. 834, 224 S.W. 459 (I920); Piercy v. Louisville \& N. Ry. Co., I98 Ky. 477, 248 S.W. I042 (I923); Stephenson v. New Orleans \& N. E. R. Co., I80 Miss. x47, I77 So. 509 (I937); Dooley v. Lehigh Valley R. Co., I30 N.J. Eq. 75, 2I A. 2d 334 (I94I). It reads as a lone dissent from the many federal court opinions stating that rights to equitable relief under collective bargaining agreements do not arise out of the RIA but out of the common law. Cases cited note 20 supra. And even where an award is obtained from the NRAB (according to the Supreme Court, on the basis of the RLA), its enforceability will depend on the validity of the claim under the common law, since the award is only entitled to prima facie weight in the enforcement proceeding, which is otherwise an ordinary civil suit. RLA $\S 3$ First (p), 48 Stat. I I85 (I934), 45 U.S.C.A. \& I53 First (p) (I943); Cook v. Des Moines Union Ry. Co., I6 F. Supp. 8Io (Iowa, I936); System Federation No. 59 v. Louisiana \& A. Ry. Co., Irg F. 2d 509 (C.A. 5th, I94I); Hanks v. Delaware \& H. R. Corp., 63 F. Supp. I6r (N.Y., I945). The right to an injunction to enforce a collective-bargaining agreement is not affected by the Norris-LaGuardia Act, 37 Stat. 72 ( $x_{932}$ ), 29 U.S.C.A. \$ ro8 (r947), prohibiting injunctions in "labor disputes." The Act has been held to apply only to disputes over changes in agreements, not to enforcement of existing contracts. See Comment, 47 Mich. L. Rev. 984, 985 (I949), and cases cited therein.

34 \& 3 First (h), 48 Stat. 1185 (1934), 45 U.S.C.A. $\S x_{53}$ First (h) (r943).

35 Ibid., at (a), (b), (c), (g). $\quad{ }^{36}$ Ibid., at (l).

37 For an invaluable inside account and criticism of the internal functioning of the NRAB, see Administrative Procedure in Government Agencies, Sen. Doc. Io, 77th Cong. Ist Sess. 
The NRAB was originally envisaged as a sort of "supreme court" for the interpretation and application of labor agreements throughout the industry. Once the large backlog of cases was disposed of and a body of precedents created, the cases referred to the NRAB would dwindle to the few difficult ones not covered by existing precedents. ${ }^{38}$ In turn, only the most difficult of these would be decided by a referee. However, the board members are not agreed as to their function. As seen by the union men, the NRAB is an extension of the adjustment machinery on company property, and a place for horse-trading and compromise. ${ }^{39}$ Although the carrier members maintain that the $N R A B$ was intended to determine rights under the agreements in an impartial, quasi-judicial manner, a process in which horse-trading and compromise have no place, $4^{\circ}$ the true attitude of members of both groups is indicated by the fact that on the busy First and Third Divisions a split in the vote of either bloc is virtually unknown. ${ }^{I}$ If a case comes up from a union which has a representative on the division, the other labor members will normally be guided by his wishes. ${ }^{2}$ The same practice prevails to a lesser extent on the carriers' side. ${ }^{43}$ Thus the merits of a particular controversy have less effect on the alignment of division members than has its bearing on the running conflict between union and carrier interests. 44

The Second Division, handling a comparatively quiet part of the industry, has disposed of its small volume of cases amicably and efficiently, and in conformity with precedent, which greatly facilitates adjustments on the property. 45 But the First and Third Divisions, dealing with the most aggressive unions in the

Part IV (194I), which appears in an abridged form in Administrative Procedure in Government Agencies, Sen. Doc. 8, 77th Cong. Ist Sess. 185 (I94I). A more emphatic and graphic earlier draft, and other revealing materials, are contained in Jones, Inquiry of the Attorney General's Committee on Administrative Procedure Relating to the National Railroad Adjustment Board (194x). See also Garrison, The National Railroad Adjustment Board-A Unique Administrative Agency, 46 Yale L.J. 567 (I937); Spencer, The National Railroad Adjustment Board (1938). These sources, the principal materials for the present comments on the NRAB's internal operation, are all at least nine years old. But the conclusions drawn from them are corroborated by more recent evidence as well. Indeed, the difficulties of the Board are so inextricable from its organization as determined by the RLA that significant improvement would be most unlikely in the absence of legislative action.

${ }^{8} 8$ Second Annual Report of the National Mediation Board 35 (1936).

39 Administrative Procedure in Government Agencies, Sen. Doc. ro, 77th Cong. Ist Sess. Part IV, at 5 (I94). "Horse-trading" is probably the best word to describe the process of grouping similar cases and balancing the awards. Rather than deadlock them all and risk having them all go to the opposition, each side agrees to concede some of the cases in exchange for others. Thus the interest of the individual claimant is sacrificed to the objective of over-all results, since all the claims might be found good if individually considered.

${ }^{40}$ Administrative Procedure in Government Agencies, Sen. Doc. Io, 77th Cong. Ist Sess. Part IV, at I8 (r94r).

4 Jones, op. cit. supra note 37 , at 151 .

42 Note 40 supra, at 17 .

44 For example, see note 39 supra.

43 Ibid.

45 Note 40 supra, at 5 . 
industry, have become forums for the expression of partisanship and carrierunion animosity. Invective and even challenges to fist-fights are more familiar than the spirit of compromise, to say nothing of impartiality. ${ }^{6}$ Instead of acquiescing in precedent, carrier members have been known to deadlock cases on points which have been uniformly decided against them in as many as three hundred previous cases, ${ }^{47}$ and inconsistent awards and interpretations are not unheard of. $4^{8} \mathrm{In}$ view of the routine character of most NRAB business, ${ }^{49}$ the atmosphere of antagonism provides the only possible explanation for the high, and rising, percentage of deadlocked cases. ${ }^{50}$

Having all these cases decided by referees involves disadvantages which have been repeatedly noted by observers of NRAB activity. ${ }^{5 x}$ The referee is employed on a daily basis, has no tenure, and is liable to disqualification on complaint of either group on a division..$^{3}$ Yet the job requires high intelligence, impartiality, and a thorough knowledge of railroad terminology and bargaining agreements. Qualified men, unable to devote full time to the work, must abandon it when their regular activities interfere, and rarely have the time to become competent and efficient referees within their period of service. ${ }^{33}$ To add to the difficulty, the First Division does not prepare opinions to accompany its awards, ${ }^{54}$ and the opinions provided by other divisions are frequently inadequate, ${ }^{55}$ making reference to the case files a cumbersome necessity for the referee in search of precedent. The unfortunate result is that a large number of NRAB cases are decided by inexperienced and uninitiated referees.

${ }^{46}$ Note 40 supra, at 5 ; Jones, op. cit. supra note 37 , at 8 r.

47 Note 40 supra, at $19,20$.

$4^{8}$ Note 40 supra, at 19.

49 It has been asserted that one group of $65^{\circ}$ cases involved only I7 principles. Tbid., at I7.

${ }^{50}$ The fifteen year record for the whole board in 17,928 cases is 9,086 decided without referee and $8,842(49 \%)$ decided with referee. In the first year the percentage of referee awards was $21 \%$, in the 15 th year it was $77 \%$. The fifteen-year proportion of deadlocks on the Third Division is $82 \%$. First Annual Report of the National Mediation Board (1935); Fifteenth Annual Report of the National Mediation Board (I949).

5x Garrison, op. cit. supra note 37 , at 593 ; Spencer, op. cit. supra note 37 , at 22; Loomis, Railway Labor Law-Practices and Problems, I6 I.C.C. Pract. J. 747, 754 (r949); Seventh Annual Report of the National Mediation Board 46 (I94I); Fifteenth Annual Report of the National Mediation Board I3 (I949).

52 If a division can't agree on a referee, the Mediation Board appoints one. But it is reluctant to name unwanted men. So a complaint (usually of bias) made by either group on a division effectively disqualifies a referee from serving again with his accusers, regardless of the merits of the accusation. Spencer, op. cit. supra note 37 , at 24; Garrison, op. cit. supra note 37 , at 593 .

53 In the fiscal year I940, five of the ten referees who served were new to the job, and in I94t the proportion was 20 of 35 . Sixth Annual Report of the National Mediation Board 32 (I940); Seventh Annual Report of the National Mediation Board 46 (r94r).

54 Note $4 \circ$ supra, at $r 8$. However, referee opinions are written in about half of the deadlocked cases in this division.

ss Note 40 supra, at 18. 


\section{III}

The bipartisan composition of the NRAB has also produced some important procedural peculiarities. Although the RLA gives individual employees the right to bring claims before the $N R A B,{ }^{66}$ the labor members, all paid union representatives, have succeeded in preventing consideration of petitions brought by employees under their own name, without representation by their bargaining agent. ${ }^{57}$ This means that dissenting members of the bargaining representative, members of minority unions and individuals who do not choose to join any union or are ineligible because of race or otherwise, have no ready access to the NRAB unless the bargaining agent is willing to represent them there..$^{8}$ And if a union which has undertaken to present a claim should settle it and withdraw the case, the claimant is bound by the settlement as far as the NRAB is concerned, even though he never consented to it. ${ }^{59}$ Thus the union

${ }^{6} \mathrm{It}$ is quite clear from the wording of the RLA that the individual claimant might bring and control his claim. "[D]isputes between an employee ... and a carrier or carriers . . . may be referred by petition of either party to the appropriate division of the Adjustment Board. ... Parties may be heard either in person, by counsel, or by other representatives, as they may respectively elect. ..." \& 3 First (i), (j), 48 Stat. II85 (I934), 45 U.S.C.A. $\$$ I53 First (i), (j) (I943). See Elgin, J. \& E. R. Co. v. Burley, 325 U.S. 7 II (I945); Patterson v. Chicago \& E. I. R. Co., 50 F. Supp. 334 (Ill., I943); Starke v. New York, C. \& St. L. R. Co., 180 F. 2d 569 (C.A. 7th, I950); McDermott v. New York Central R. Co., 32 F. Supp. 873 (N.Y., I940).

57 E.g., Burke v. Union Pac. R. Co., I29 F. 2d 844, 845 (C.A. Ioth, I942). Authority cited note 40 supra, at 7 . A few isolated cases on the Fourth Division involving employees who didn't belong to an organized craft or class have been the only deviations from this practice. A majority vote of the division is necessary to an assumption of jurisdiction. Since there is no provision for appointment of referees to resolve procedural deadlocks, the invariable labor dissent in these cases has the effect of a final refusal to consider the individual's claim. In one case where a referee did decide the issue, the labor view triumphed. Rudd v. Minneapolis, St. P. \& S. Ste. M. Ry. Co., N.R.A.B. 3d Div., Award No. I7I8 (I942). The labor view is formally based on the RLA requirement that disputes be handled "in the usual manner" on the property before they may be referred to the NRAB. $\$ 3$ First (i), 48 Stat. 1185 (1934), 45 U.S.C.A. \& 153 First (i) (1943). The "usual manner," it is said, is by action of the bargaining agent, not of the individual or of the minority union. Some unions have had the foresight to insert provisions in the bargaining agreement that the elected representative shall have the exclusive right to present grievances. This makes an inquiry into custom unnecessary. See Rudd v. Minneapolis, St. P. \& S. Ste. M. Ry. Co., supra; 40 Ops. U.S. Att'y Gen. 254 (I942). But the principle of the Elgin case would make such provisions invalid as against the public interest. Elgin, J. \& E. R. Co. v. Burley, 325 U.S. 7 II (I945); see 40 Ops. U.S. Att'y Gen. 494 (r946); cf. Edwards v. Capital Airlines, I76 F. 2d 755 (App. D.C., 1949). The reason why the practice is so important to the represented labor unions is the incentive to union membership which results from this requirement. In one instance where a division refused to allow a union other than the bargaining agent to bring claims on behalf of its members, the union lost so many members that its CIO charter was taken away. See United R.R. Workers v. Atchison, T. \& S. F. Ry. Co., 89 F. Supp. 666, 668 (Ill., 1950).

${ }^{8}$ Ibid.; see Starke v. New York, C. \& St. L. R. Co., 180 F. 2d 569 (C.A. 7 th, r95o); authority cited note 40 , at 7 n. 16 (194r).

s9 But see Elgin, J. \& E. R. Co. v. Burley, 325 U.S. 7rr, 7 I8 (I945); Rogers v. Union Pacific R. Co., I45 F. 2 d II9, I2I (C.A. gth, I944). The Elgin case held that a union which was authorized by an employee to present a claim to the NRAB was not empowered to compromise it without additional authorization. Generally stated, the theory of the case is that the claim 
bargaining agent is the keeper of the keys to NRAB relief, which has now become the only relief available anywhere. The ascendant union, having been elected bargaining representative, can and does use its exclusive right of access to the NRAB to consolidate its position vis- $d$-vis competing unions. ${ }^{60}$ This result is in direct conflict with the view taken by the Supreme Court in Elgin, J. \& $E$. R. Co. v. Burley, ${ }^{6 \mathrm{x}}$ that the bargaining agent's power to determine the rights of members of the bargaining unit is limited to the making of the agreement, ${ }^{62}$ and that rights under an effective agreement belong to each member of the unit independent of the desires of the elected representative. ${ }^{63}$ In the past, an employee who could not secure the cooperation of his bargaining agent, could nevertheless get relief in the courts. ${ }^{6} 4$ This situation could be regarded as beyond the scope of the Slocum rule, so that judicial relief might continue, or perhaps the NRAB will be required to decide such cases. ${ }^{65}$ Otherwise the Slocum case will result in the denial of remedy (and therefore of rights) to these employees.

belongs to the employee, and he is bound by union action (including presentation to the NRAB) only to the extent he has consented to it. After the decision was handed down, the carrier members on the First Division stated that unions which wanted to present claims would have to show a power of attorney from the individual employees they were representing. At this the labor members walked out, and the Division ceased to operate until the carrier men agreed to abandon the position. Twelfth Annual Report of the National Mediation Board 64 (I946). So the Elgin decision had no effect on the NRAB practice of regarding the claim as belonging to the union rather than the individual. See Starke v. New York, C. \&St. L. R. Co., 180 F. 2d 569,573 (C.A. 7 th, $x 95^{\circ}$ ). The courts have usually taken the Elgin view that the employee's rights under the collective bargaining agreement are independent of the union which made the agreement. Starke v. New York, C. \& St. L. R. Co., supra; Reynolds v. Denver \& R. G. W. R. Co., 174 F. 2d 673 (C.A. roth, I949); Kordewick v. Indiana Harbor Belt R. Co., x57 F. 2d 753 (C.A. 7th, I946); Gaskill v. Roth, I5 I F. 2d 366 (C.A. 8th, x945); Piercy v. Louisville \& N. Ry. Co., 198 Ky. 477, 248 S.W. I042 (1923). Contra: Hughes v. Chicago, R.I. \& P. R. Co., I8 C.C.H. Lab. Cas. $\uparrow 65,882$ (D.C. Okla., I950) (union member was bound by union's interpretation of agreement).

${ }^{60}$ E.g., see United R.R. Workers v. Atchison, T. \& S. F. Ry. Co., 89 F. Supp. 666, 668 (Ill., I950), which describes how a minority union lost most of its membership and then its CIO charter because it couldn't represent its members before the NRAB.

6x 325 U.S. $71 x$ (x945).

$$
62 \text { Ibid., at } 733 \text {. } \quad{ }_{3} \text { Ibid., at } 736 .
$$

${ }_{64}$ E.g., Rogers v. Union Pacific R. Co., $\mathrm{r}_{45}$ F. 2d Irg (C.A. gth, I944). But refusal of the NRAB to accept jurisdiction of a case has not made the case one arising under the RLA so as to qualify it for federal jurisdiction in the absence of diversity. McDermott v. New York Central R. Co., 32 F. Supp. 873 (N.Y., I940); Burke v. Union Pacific R. Co., I29 F. 2d 844 (C.A. Ioth, I942). However, these cases were decided at a time when the state courts were still available.

65 There is a precedent for such a procedure. Patterson v. Chicago \& E. I. R. Co., $5 \circ$ F. Supp. 334 (Ill., I943); cf. Delaware \& Hudson R. Corp. v. Williams, I29 F. 2d Ix (C.A. 7th, I942). However, labor members might walk out (as they did after the Elgin decision, see note 59 supra), if the procedure became commonplace. Administrative Procedure in Government Agencies, Sen. Doc. 10, 77 th Cong. Ist Sess. Part IV, at 10 (194I). More important would be the claimant's poor chances of getting a fair hearing, since he would start out with the labor members against him and the carrier members motivated by a contrary interest. See Edwards v. Capital Airlines, I76 F. 2d 755 (App. D.C., 1949). 
The RLA limits the jurisdiction of the NRAB to "disputes between an employee or group of employees and a carrier or carriers. ..." Although the NRAB recognizes that this provision does not include disputes between employees, ${ }^{67}$ it disposes of certain of them anyway. ${ }^{68}$ Some courts have asserted that the NRAB has no jurisdiction in inter-employee disputes, ${ }^{69}$ and have occasionally denied the force of res judicata to NRAB awards which attempted to dispose of them. ${ }^{70}$ However, the Supreme Court may have accepted the view that the NRAB can deal with inter-employee disputes, since both the Slocum and Piney cases involved controversies between two unions. But neither case is by any means a square holding on the point, ${ }^{7 x}$ and it is to be hoped that the courts will be permitted to continue to take these cases, since the NRAB is so ill-suited to deal with them. The seniority dispute, the employee-bargaining agent dispute, and the inter-union jurisdictional dispute are the most frequent types encountered. A glance at each will disclose its importance to the collective bargaining system, the inadequacy of its treatment by the NRAB, and the evil of the Slocum rule should it result in denying access to the courts in these cases.

Seniority rights give a measure of security in one's employment, a thing of increasing value as the worker gets older and new jobs become harder for him to obtain. When a man asserts seniority rights under a contract, he is of necessity claiming a preference over other employees and placing their own seniority

66 \& 3 First (i), 48 Stat. Ir85 (1934), 45 U.S.C.A. $\&$ r53 First (i) (r943).

${ }_{67}$ See Crowell v. Palmer, I34 Conn. 502, 509, $5^{8}$ A. $2 d$ 729, 733 (I948); Order of R.R. Telegraphers v. New Orleans, T. \& M. Ry. Co., I56 F. 2d r, 5 (C.A. 8th, I946).

${ }^{68}$ See Order of R.R. Telegraphers v. Clinchield R. Co., N.R.A.B. 3 d Div., Award No. 844 (r939). The carrier members of the NRAB have always maintained that interested employees should be notified in seniority claims, but this contention has been rejected by labor members and referees on the theory that the NRAB only deals with union-carrier disputes. But a seniority dispute is so obviously not a union-carrier controversy that the labor members can only be using the argument of limited jurisdiction to take advantage of nonunion interests by excluding them from proceedings in which they have an important stake. If the labor members were consistent in applying the limitation they would not accept a seniority dispute in the first place.

69 Crowell v. Palmer, I34 Conn. 502, 509, 58 A. 2 d 729, 733 (I948); Long v. Van Osdale, 26 N.E. 2d 69, 74 (Ind. App., I940); Order of R.R. Telegraphers v. New Orleans, T. \& M. Ry. Co., I56 F. 2d I, 5 (C.A. 8th, I946); Texas \& Pac. Ry. Co. v. Brotherhood of R.R. Trainmen, 60 F. Supp. 263, 274 (La., I945), rev'd r59 F. 2d 822 (C.A. 5th, r947); Stephenson v. New Orleans \& N. E. R. Co., I80 Miss. I47, 166, I77 So. 509, $5 \mathrm{I}_{4}$ (1937). But see United States ex rel. Deavers v. Missouri-K.-T. R. Co., I 7 I F. 2d 96r, 963 (C.A. 5th, I949).

70 Stephenson v. New Orleans \& N. E. R. Co., I80 Miss. 147, I77 So. 509 (I937); Order of R.R. Telegraphers v. New Orleans, T. \& M. Ry. Co., I56 F. 2d x (C.A. 8th, I946); Griffin v. Gulf \& Ship Island R. Co., I98 Miss. 458, 2 I So. $2 d 814$ (r945).

$7 x$ Because the law is not clear on whether the type of dispute involved is actually one between employee groups or strictly a union-carrier affair (see text at note 85 infra) these decisions need not have been intended to apply to clear-cut inter-employee controversies. But the language of the Slocum opinion is indicative of a strong inclination to expand NRAB jurisdiction to all cases involving contract interpretations and applications in the railroad industry. The seniority dispute is a classic inter-employee controversy under this general heading, and one which the NRAB has been deciding since its inception. 
rights in jeopardy. As a rule, the carrier has no interest in such a dispute. The real parties in interest are the individual employees immediately affected. As this dispute comes before the NRAB, the union bargaining agent is petitioning for relief against the carrier on behalf of certain employees. ${ }^{72}$ But the men who would be adyersely affected by an award for these employees will not be notified or heard by the NRAB, due to the stand taken by its union members. ${ }^{73}$ The courts, in contrast, hold that employees adversely affected by a seniority claim have property (seniority rights) at stake which may not be taken from them without due notice and hearing; and they have repeatedly held NRAB awards invalid for failure to comply with these requirements. 74

When an employee, union or nonunion, has a grievance against the bargaining agent, he is without a spokesman before the NRAB and cannot hope for

7 E.g., Order of R.R. Telegraphers v. Clinchfield R. Co., N.R.A.B. 3 d Div., Award No. 844 (1939).

73 Carrier respondents and carrier members have often moved to notify and hear these other employees. But the labor panel has always voted the opposite way, resulting in a deadlock and inaction. Their reasoning is set out in note 68 supra. See also Hutcheson, $J$., concurring in result in Estes v. Union Terminal Co., 89 F. 2d 768,774 (C.A. 5th, I937). The result of the practice is that the union bargaining agent is unopposed in NRAB proceedings by the only people who stand to lose by an award to the union. It.should also be remembered that these other employees cannot bring their own claims to the NRAB without the active cooperation of the same bargaining agent which is here opposing them.

${ }^{4}$ Nord v. Griffin, 86 F. 2d 48I (C.A. 7th, I936); Watson v. Missouri-K.-T. R. Co., I73 S.W. $2 d$ d 357 (Tex. Civ. App., I943) (enforcement of awards enjoined); R.R. Yardmasters v. Indiana Harbor Belt R. Co., 70 F. Supp. 914 (Ind., 1947) (enforcement denied); see Lane v. Union Terminal Co., 12 F. Supp. 204 (Tex., I935); Estes v. Union Terminal Co., 89 F. 2d 768 (C.A. 5th, 1937); cf. Primakow v. Ry. Express Agency, 56 F. Supp. 4I3 (Wis., r943); Brand v. Pennsylvania R. Co., 22 F. Supp. 569 (Pa., I938) (awards of system boards enjoined). But see R.R. Yardmasters v. Pittsburgh \& L. E. R. Co., 39 F. Supp. 876 (Ohio, I940), where a suit for injunction against enforcement of an award was dismissed because there was no provision for such an attack under the RLA. The court said that the plaintiff would have the right to intervene in the enforcement proceeding, but note that if the carrier voluntarily complies with the award, there will be no enforcement proceeding.

While the courts agree that seniority rights under an existing contract are property rights, a change in the agreement which results in altering them is not a violation of due process, so that union activities in negotiating a new agreement are not subject to due process limitations in favor of individual employees. Division 525 v. Gorman, I33 F. 2d 279 (C.A. 8th, I943); Austin v. Southern Pacific Co., 50 Cal. App. 2d 292, 123 P. 2d 33 (I942); Wooldridge v. Denver \& R. G. W. R. Co., I18 Colo. 25, I9I P. 2d 882 (I948). Whether the rights are to be looked on as property rights in the constitutional sense or not, the fact remains that they are of tremendous importance to individual employees and it is manifestly unfair to give unions the power to nullify an individual's seniority rights under a continuing agreement. Changes in the bargaining agreement which affect individual rights might be justified on the ground that the union must be free to represent the interest of the majority of the bargaining unit as it sees fit. But no reason appears why the majority should have anything to say about an individual employee's rights already accrued under an existing agreement. See note rog infra. Yet under the present NRAB setup the union can decide which seniority grievances shall be heard by the NRAB, and prosecute the ones it chooses without opposition from employees adversely affected. Since the Slocum case, the employee whose union doesn't like his complaint (or him) has no forum at all in which to seek relief. Members of the bargaining unit are left at the mercy of their bargaining agent. See Starke v.

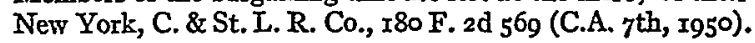


relief from it. ${ }^{75}$ Yet discrimination by representative unions against nonunion men, and their own members as well, is a frequent phenomenon in the field. ${ }^{76}$ The problem is especially pressing in the case of Negroes, who cannot join many of the national unions. ${ }^{77}$ Fireman Tunstall was able to persuade a court to enjoin the Brotherhood of Locomotive Firemen and Enginemen from negotiating a discriminatory agreement with the carrier, ${ }^{78}$ but this was outside NRAB jurisdiction. Suppose he should discover that the union was discriminating in keeping the seniority lists under a nondiscriminatory contract. Under a literal reading of the Slocum opinion, exclusive jurisdiction of this complaint would be in the NRAB, First Division, the labor members of which are paid by allwhite unions, ${ }^{79}$ including this same Brotherhood. Even if Tunstall, although necessarily without union representation, could succeed in compelling the $\mathrm{NRAB}$ to consider his case, he would start out with the five labor men against him. Whether the case even got as far as a referee would depend solely on the interest or mood of the carrier members. And should the decision go against Tunstall, there would be no way of obtaining judicial review under the RLA as currently interpreted. ${ }^{80}$ Unless the courts are given original or appellate jurisdiction, perhaps on the same constitutional basis as in the Steele ${ }^{8 \mathrm{x}}$ and Tunstall cases, the purpose of those decisions will be frustrated, for bargaining agents in applying a contract will be able to accomplish with impunity discrimination which is enjoinable if attempted at the negotiation stage. The courts have had

75 See Crowell v. Palmer, 134 Conn. 502, 58 A. 2d 729 (1948); Griffin v. Gulf \& Ship Island R. Co., 198 Miss. 458 , 2 I So. $2 \mathrm{~d} 8 \mathrm{I} 4$ (I945); text at note 56 supra.

${ }^{76}$ Discrimination against nonunion men: Crowell v. Palmer, I34 Conn. 502, $58 \mathrm{~A} .2 \mathrm{~d} 729$ (1948); System Federation No. 9 r v. Reed, 180 F. 2d 991 (C.A. 6th, I950); Griffin v. Gulf \& Ship Island R. Co., 198 Miss. 458, 2I So. 2d 8I4 (I945); Long v. Van Osdale, 26 N.E. $2 d$ ${ }_{69}$ (Ind. App., 1940) (all involving union practices in maintaining seniority lists). Complaints against union by its own members: Dooley v. Lehigh Valley R. Co., r3o N.J. Eq. 75, 2I A. 2d 334 (I94r); Capra v. Local Lodge No. 273, ro2 Colo. 63, 76 P. 2d 738 (1938); Piercy v. Louisville \& N. Ry. Co., I98 Ky. 477,248 S.W. IO42 (1923).

These are cases dealing with practices under an existing contract. They are not cited as proof of the strong tendency toward discrimination, which is more evident from materials cited note 77 infra, but they do show the possibilities for abuses in applying a nondiscriminatory agreement.

${ }_{77}$ See Steele v. Louisville \& N. R. Co., 323 U.S. I92 (r944); 56 Yale L.J. 73 I (1947), noting Betts v. Easley, r6I Kan. 459, 169 P. 2d 83I (1946); Summers, The Right to Join a Union, 47 Col. L. Rev. 33 (1947).

Because the Brotherhood of Railroad Trainmen wouldn't accept Negroes as members, Negro brakemen were forced to organize independently. Now B.R.T. pressure to get all braking work for its all-white membership is resulting in a bitter and protracted jurisdictional dispute involving the Brotherhood and numerous Negro unions.

${ }^{8}$ Tunstall v. Brotherhood of Locomotive Firemen \& Enginemen, 323 U.S. 210 (1944).

79 Brotherhood of R.R. Trainmen, Brotherhood of Locomotive Firemen \& Enginemen, Brotherhood of Locomotive Engineers, Order of Ry. Conductors, and Switchmen's Union of North America. See Hampton v. Thompson, I7 I F. 2d 535, 536 n. 2(xo) (C.A. 5th, 1949).

${ }^{80}$ See text at note ror infra.

${ }^{8 x}$ Steele v. Louisville \& N. R. Co., $3^{23}$ U.S. $1_{92}$ (I944). 
no difficulty in dealing with these cases, ${ }^{82}$ once again supplying a need not met by the NRAB.

Union pressure to expand into job areas occupied by other unions sometimes results in a contract which purports to govern employment already covered by another agreement. ${ }^{83}$ The carrier complies with the new agreement ${ }^{8_{4}}$ and thereby incurs the dissatisfaction of the union which made the older contract. As it comes before the NRAB, such a dispute is in the form of one or two unioncarrier controversies. The claims of each union under its contract are considered as independent demands on the carrier. If both agreements cover the same work, two awards may issue, and the carrier must change one of the agreements to remove the overlap if it wishes to cease paying twice for the same work. ${ }^{85}$ But the NRAB will not attempt to decide which union has jurisdiction over the work and the right to contract for it. It limits itself to the application of agreements which have in fact been made, without attempting to resolve conflicts between them or to determine who shall contract for the work in the future.

The courts have taken various views in such jurisdictional disputes. Like the NRAB, some say the controversy over who has the right to contract for the work is not justiciable and must be worked out by unions and carrier through negotiation and bargaining. ${ }^{86}$ Other courts have given relief, basing it on the theory of interference with advantageous relations, and giving the disputed jobs to the union originally having jurisdiction over them. ${ }^{87}$ However, the court

${ }^{82}$ Cases cited note 8 supra.

${ }_{83}$ The most prominent example of this is the nationwide campaign of the Brotherhood of Railroad Trainmen to take braking work from members of various Negro unions. See Howard v.Thompson, 72 F. Supp. 695 (Mo., I947); Randolph v. Missouri-K.-T. R.Co., 68 F. Supp. 1007 (Mo., I946); Hampton v. Thompson, I7 F. 2d 535 (C.A. 5th, r948). For other areas of interunion friction see Order of R.R. Telegraphers v. New Orleans, T. \& M. Ry. Co., 6r F. Supp. 869 (Mo., 1945) (Telegraphers and Brotherhood of Ry. \& S.S. Clerks); Illinois Central R. Co. v. Brotherhood of R.R. Trainmen, 83 F. Supp. $93^{\circ}$ (Ill., I949) (Trainmen and Order of Ry. Conductors).

$8_{4}$ This may be done because of the same pressure which caused the carrier to make the agreement (usually the case when work is taken from lower-paid Negroes) or because the carrier can effect economies through job combinations under the new agreement.

${ }_{85}$ "[The NRAB] can not alter an agreement for the relief of either [carrier or union], even though it might appear that the work was also covered by an agreement with [another union]. ... We see no way in which this Board . . . could save a carrier who has executed two agreements, the scope rule of which agreements covers the same work; nor do we believe it was the intention of the Congress ... to permit the employes covered by one such agreement to intervene and be heard in a claim filed before this Board by the employes covered by the other agreement." Brotherhood of Ry. \& S.S. Clerks v. Gulf Coast Lines, N.R.A.B. 3d Div., Award No. 2253 (1943).

${ }^{86}$ This is the view on the fifth and eighth circuits, which refer complaints of this type to the $\mathrm{NRAB}$, understanding that the NRAB will not attempt to remove the overlap but merely make the carrier perform each contract according to its terms. Hampton v. Thompson, I7I F. 2d 535 (C.A. 5th, I948); Missouri-K.-T. R. Co. v. Randolph, I64 F. 2d 4 (C.A. 8th, 1947); Order of R.R. Telegraphers v. New Orleans, T. \& M. Ry. Co., 6r F. Supp. 869 (Mo., I945), rev'd on other grounds I56 F. 2d I (C.A. 8th, I946).

${ }^{87}$ Randolph v. Missouri-K.-T. R. Co., 68 F. Supp. I0o7 (Mo., I946), noted 60 Harv. L. Rev. $83^{2}$ (r947), rev'd I64 F. 2d 4 (C.A. 8th, I947); Hunter v. Atchison, T. \& S. F. Ry. Co., I7 F. 2d 594 (C.A. 7 th, I948). 
may require the parties to have their separate contract rights determined by the NRAB before coming into court. ${ }^{88}$ If this requirement is continued, the Negro unions, which have the most frequent cause to complain, may be unable to get relief because of bias on the First Division, which has jurisdiction of most of the areas which concern them. ${ }^{89}$ Other courts maintain that the NRAB has exclusive jurisdiction in this type of case, ${ }^{90}$ but it appears that some of these, at least, are unaware of the treatment given such cases by the NRAB, which does not recognize a conflict between the two unions. Although it stated that the NRAB had exclusive jurisdiction of the dispute, one court enjoined enforcement of the ensuing NRAB awards because each was made in the presence of only one of the unions, and therefore failed to accord due process to the absent union. ${ }^{9 x}$ Implicit in such action, also taken by other courts, ${ }^{92}$ is the view that there is a justiciable controversy over the right to contract for the work in question. Although the Supreme Court held in the Slocum case that the NRAB had exclusive primary jurisdiction of a jurisdictional dispute, the Court did not make an explicit endorsement of the agency's procedure in treating this type of case. In view of the conflict in lower court cases it is unlikely that the Court would have left such an endorsement implicit if it had been intended. If the issue were directly considered, it seems probable that the Court would hold the National Mediation Board, not the NRAB, to have exclusive jurisdiction over the right to contract, pursuant to the NMB's power to determine the class or craft which shall be represented by a bargaining agent. ${ }^{93}$

${ }^{88}$ Order of Ry. Conductors v. Pitney, 326 U.S. 56I (I946); Order of R.R. Telegraphers v. New Orleans, T. \& M. Ry. Co., I56 F. 2d I (C.A. 8th, 1946); Griffin v. Illinois Central R. Co., 88 F. Supp. 552 (IIl., I949).

${ }^{89}$ See Hampton v. Thompson, I7r F. 2d 535,536 n. 2(xo) (C.A. $5^{\text {th, }}$ x948). The First Division labor members are all representatives of all-white unions (listed note 79 supra).

${ }_{90}$ Cases cited note 86 supra; Illinois Central R. Co. v. Brotherhood of R.R. Trainmen, 83 F. Supp. 930 (Ill., r949); In re Central R. Co. of N.J., I45 F. 2d 35I (C.A. 3d, I944), modified sub nom. Order of Ry. Conductors v. Pitney, 326 U.S. 56I (I946); Hampton v. Thompson I7 F. 2d 535 (C.A. 5th, I948).

${ }^{9}$ Missouri-K.-T. R. Co. v. NRAB, I8 C.C.H. Lab. Cas. 165,8I4 (D.C. Ill., I950). The parties were sent back to the NRAB for a rehearing with both unions present, but the Board has since declined to grant this, and the court now has the case again.

92 Templeton v. Atchison, T. \& S. F. Ry. Co., 84 F. Supp. I62 (Mo., I949), aff'd sub nom. Brotherhood of R.R. Trainmen v. Templeton, I8I F. 2d 527 (C.A. 8th, I950); Griffin v. Illinois Central R. Co., 88 F. Supp. $55^{2}$ (IIl., r949).

93 Switchmen's Union v. National Mediation Board, 320 U.S. 297 (1943); RLA § 2 Ninth, 48 Stat. Ir 85,45 U.S.C.A. \& I52 Ninth (1943).

Under the RLA, the National Mediation Board has the function of determining the class or craft which is to be represented by a single bargaining agent and governed by its contract. If these classes are determined by kind of employment rather than union affiliation (and they should be) it would appear that two unions could not both be qualified to contract for the same work on the same road. The proper scope of a contract should be the class or craft as determined by the Mediation Board, not the scope agreement contained in particular contracts. Once the bargaining unit is determined, the elected representative is under a duty not to discriminate against anyone in it, Negro or white, union member or unaffiliated employee. Steele v. Louisville \& N. R. Co., 323 U.S. I92 (I944). This line of reasoning was suggested to 
In view of the adventitious character of NRAB determinations, it is unfortunate that they should be given the finality which the law now requires. The RLA provides that $\mathrm{NRAB}$ decisions shall be final and binding, 94 and makes no provision for court review except in a suit for enforcement of an award granting relief. The "final and binding" provision does not apply to the enforcement suit,95 which proceeds "as other civil suits, except that ... the findings and order of the [NRAB] shall be prima facie evidence of the facts therein stated. ..."96 Thus the only person who can bring a decision of the NRAB into court under the RLA is the plaintiff who wins an award. The defendant, always a carrier, can have judicial review only if the claimant sues to enforce, and must decline to comply in order to bring this about.97 In so doing it risks accrual of two years' damages in the event the beneficiaries of the award wait the statutory limit before filing suit for enforcement..$^{98}$ Some unions have made it a practice to coerce compliance by threat of strike, thus avoiding an enforcement proceeding and the possibility of reversal of an NRAB decision in their favor. 99 Carriers have attempted, without success, to obtain judicial review on their own motion by suit for declaratory judgment. ${ }^{\text {.00 }}$

the courts in Howard v. Thompson, 72 F. Supp. 695 (Mo., I947), but has not yet been worked out in detail, partly because many of the courts are still preoccupied with the role of the NRAB in treating these cases.

$94 \S_{3}$ First (m), 48 Stat. $1 \times 85$ (1934), 45 U.S.C.A. § I53 First (m) (1943).

${ }_{95}$ Dahlberg v. Pittsburgh \& L. E. R. Co., r38 F. 2 d I2I (C.A. 3d, I943). There is no express limitation on the provision except in the case of money awards, but how these are to be treated differently is not set out.

${ }_{96} \S 3$ First (p), 48 Stat. 1185 (I934), 45 U.S.C.A. $\$$ I53 First (p) (I943). The weight given the NRAB award varies from court to court. But the general rule is that the enforcement proceeding is a trial de novo, and the claim must have a basis in law independent of the award if enforcement is to be given. Trial de novo: Order of Sleeping Car Conductors v. Pullman Co., 47 F. Supp. 599 (Wis., x942); Hanks v. Delaware \& H. R. Corp., 63 F. Supp. I6I (N.Y., I945); Swift v. Chicago \& N.W. Ry. Co., 84 F. Supp. II6 (Iowa, I944). Independent basis in law: Cook v. Des Moines Union Ry. Co., I6 F. Supp. 810 (Iowa, I936); System Federation No. 59 v. Louisiana \& A. Ry. Co., 30 F. Supp. 909 (La., r940), aff'd IIg F. 2d 509 (C.A. 5th, I94I); Dahlberg v. Pittsburgh \& I. E. R. Co., I38 F. $2 \mathrm{~d}$ I2I (C.A. 3d, I943). Thus in spite of the "final and binding" provision, a district court may reverse an NRAB decision on the merits.

97 This has been held not to deny due process to the carrier. The opportunity to defend in the suit for enforcement is deemed a sufficient safeguard to the carrier. Washington Terminal Co. v. Boswell, I24 F. 2d 235 (App. D.C., I94I); Cook v. Des Moines Ry. Co., r6 F. Supp. 810 (Iowa, 1936).

${ }_{98}^{8}$ See Washington Terminal Co. v. Boswell, r24 F. 2d 235, 247 (App. D.C., I94I); RLA $\S 3$ First (g), 48 Stat. 1185 (I934), 45 U.S.C.A. § I $_{33}$ First (g) (r943).

${ }^{99}$ See Washington Terminal Co. v. Boswell, I24 F. 2d 235, 246 (App. D.C., I94I); Shipley v. Pittsburgh \& L. E. R. Co., 83 F. Supp. 722, 76x (Pa., I949); Garrison, op. cit. supra note 37 , at 59 I n. 94 .

roo Washington Terminal Co. v. Boswell, I24 F. 2d 235, 245 (App. D.C., I94I); New Orleans P. B. R. Comm'n v. Ward, 182 F. 2d 654 (C.A. 5th, I950). 
In a more serious position is the claimant who is denied relief by the NRAB. Since he has no award to enforce, there is no RLA provision under which he can bring the decision into court, and the "final and binding" stipulation has been held to preclude an original court suit. ${ }^{\text {tor }}$ Although the constitutionality of this limitation has been occasionally questioned, ${ }^{\mathrm{x}}{ }^{2}$ claimants have repeatedly been refused judicial consideration of claims already rejected by the NRAB. ${ }^{x 3}$ The only direct pronouncements by the Supreme Court, both in minority opinions, also took this view. ${ }^{\mathrm{x} 4}$ These cases were decided on the theory that originally the claimant could have chosen to sue in court intead of submitting the case to the NRAB, so that even if NRAB procedure were lacking in due process, the claimant would be estopped to complain of it. Under the new ruling that the $N R A B$ has exclusive primary jurisdiction, this rationale is no longer available, and a reconsideration of the constitutionality of the RLA review provisions should be forthcoming. And as Justice Reed pointed out in his Slocum dissent, the NRAB lacks characteristics and procedures which are essential in a tribunal capable of making unreviewable adjudications under traditional standards of fairness and due process. ${ }^{\mathrm{I05}}$

ror Cases cited note 103 infra. But it is hard to see why NRAB decisions against a claimant should be entitled to absolute finality when decisions for claimant by the identical tribunal are worth only prima facie weight in the reviewing court.

It has been suggested by Holly, $J$., in Hargis v. Wabash R. Co., I63 F. 2d 608, 6x I (C.A. 7 th, 1947), that adverse decisions of the NRAB are reviewable under the Administrative Procedure Act $\S$ Io(e), 60 Stat. 237 (I946), 5 U.S.C.A. $\$$ I009(e) (Supp., I949). However, "agencies composed of representatives of the parties or of representatives of organizations of the parties to the disputes determined by them" are excluded from the review provisions of the Act, Ibid., at $\$ 2(a)$ and $\S \operatorname{roor}(a)$. Furthermore, statutes precluding judicial review take precedence over the review provisions. Ibid., at $\S$ Io and $\S$ Ioog. And an explicit statutory prohibition is not necessary. A judicial decision that the statute so operates (of which there have been many on this point; see note ro3 infra) is sufficient. Kirkland v. Atlantic Coast Line R. Co., I67 F. 2d 529 (App. D.C., x948).

${ }^{102}$ Washington Terminal Co. v. Boswell, r24 F. 2d 235, 245 (App. D.C., I94I); Watson v. Missouri-K.-T. R. Co., I73 S.W. 2d 357, 362 (Tex. Civ. App., I943); Dahlberg v. Pittsburgh \& L. E. R. Co., I38 F. 2 d I21, I23 (C.A.3d, I943).

${ }^{203}$ Berryman v. Pullman Co., 48 F. Supp. 542 (Mo., I942); Hecox v. Pullman Co., 85 F. Supp. 34 (Wash., I949); Ramsey v. Chesapeake \& Ohio R. Co., 75 F. Supp. 740 (Ohio, I948); Williams v. Atchison, T. \& S. F. Ry. Co., 356 Mo. 967,204 S.W. 2 d 693 (r947), cert. den. 333 U.S. 854 (I948); Hargis v. Wabash R. Co., I63 F. 2d 608 (C.A. 7th, I947), noted 96 U. of Pa. L. Rev. 429 (I948); Reynolds v. Denver \& R. G. W. R. Co., I74 F. 2 d 673 (C.A. Ioth, I949); Austin v. Southern Pacific Co., $5 \circ$ Cal. App. 2d 292, I23 P. 2d 39 (1942). But compare Rogers v. Union Pacific R. Co., I45 F. 2d xIg (C.A. gth, I944); see opinion of Holly, D. J., in Hargis v. Wabash R. Co. supra; dissenting opinion of Stephens, J., in Washington Terminal Co. v. Boswell, I24 F. 2d 235, 269 (App. D.C., I94I); cf. Edwards v. Capital Airlines, I76 F. $2 d 755$ (App. D.C., r949).

rof Opinion of Justice Frankfurter (concurred in by three others) in Elgin, J. \& E. R. Co. v. Burley, 325 U.S. 7 II, 749 (1945), citing Berryman v. Pullman Co., 48 F. Supp. 542 (Mo., 1942), with approval; opinion of Justice Reed in Slocum v. Delaware, L. \& W. R. Co., 339 U.S. 239, 252 (1950), noting the same line of decisions, but with alarm. The view is also manifested in the denial of certiorari in a case which squarely raised this issue, Williams v. Atchison, T. \& S. F. Ry. Co., 356 Mo. 967,204 S.W. $2 d 693$ (I947), cert. den. 333 U.S. 854 (I948). ${ }_{105}$ Note ro7 infra. 
$V^{*}$

There is a need for a special tribunal to deal with disputes under railroad collective-bargaining agreements because of the large volume of cases, and the desirability of having the agreements uniformly and expertly interpreted and applied from case to case. But the NRAB as presently constituted is unfit to deal adequately with many types of disputes in the field. The bipartisan panel settles cases by compromise rather than on the merits, and many of the deadlocks are resolved by inexperienced referees. The NRAB limits claimants to those who can obtain representation by their bargaining agent, and favors the represented employees in treating inter-employee disputes. Many of the inequalities caused by these characteristics were mitigated by the availability of judicial relief. To the extent that the Slocum case will restrict resort to the courts it will magnify the consequences of these deficiencies and detract from the adequacy of the pre-existing overall NRAB-court treatment of these cases.

However, the courts can help to safeguard interests left unprotected by the Slocum rule by taking cases which the NRAB declines to accept and by allowing judicial review of NRAB decisions against petitioner, which are not otherwise reviewable under the RLA. ${ }^{x 6}$ It would seem that the NRAB in its present form could not treat inter-employee disputes so as to satisfy judicial requirements of due process. Even if the Board gave notice and hearing to all interested parties, the represented union interest would have a great advantage because of the composition of the tribunal. ${ }^{107}$ Perhaps original resort or removal to the courts will be permitted in this limited class of cases as well. Such a system

${ }^{206}$ "[The Court] must in the future build up a complex system of review, or it must say that Congress intended to leave the rights of many individuals and organizations to the unreviewable discretion of a privately selected board.... This Court may be hard put to protect the rights of minorities under these circumstances." Justice Reed, dissenting in Slocum v. Delaware, L. \& W. R. Co., 339 U.S. 239, 252-54 (I950).

${ }^{107}$ Justice Reed, dissenting in Slocum v. Delaware, L. \& W. R. Co., 339 U.S. 239, 252 (r950), said: "[T]he Court says that Congress has forced the parties into a forum that has few of the attributes of a court, but which may be the final judge of the rights of individuals. . . When Congress has created ... administrative agencies and special courts [with great sweep], it has carefully outlined their powers, provided stated protections for individual rights, and has furnished neutral officials. But here, although none of these protections have been provided, the Court finds an underlying purpose in Congress to abolish, without discussion, judicial jurisdiction. When an administrative body varies so markedly from the kind which experience has shown may safely be given final power over people's rights, it should not be assumed that Congress intended the primary jurisdiction of the Board to be exclusive. ... The decision of the Court places it in a dilemma of its own creation-it must in the future build up a complex system of review, or it must say that Congress intended to leave the rights of many individuals and organizations to the unreviewable discretion of a privately selected board."

See Edwards v. Capital Airlines, I76 F. 2d 755 (App. D.C., I949), in which nonunion employees sued in court for reinstatement after a bipartisan system board set up under the RLA had dismissed the complaint. The union bargaining agent had actively opposed the plaintiff in the hearings before the system board. The carrier was not interested in the dispute. Although there was no RLA provision for it in such a case, the court said that plaintiffs were entitled to judicial review because the administrative remedies did not adequately guarantee a fair hearing in this case, since half the members of the tribunal were union members, and the carrier members had no stake in the controversy. 
would fail to realize the Supreme Court's objective of uniform treatment of railroad collective-bargaining agreements, but the NRAB, too, is not beyond reproach in this respect. Outweighing this disadvantage is the desirability, if not necessity, of ensuring a fair hearing and equal justice to all employees.

Uniformity and fairness could both be achieved under the Slocum rule were the NRAB reconstituted as an impartial tribunal. ${ }^{108}$ It could combine the procedural and adjudicative advantages of a court with the specialized knowledge of an administrative agency. It could provide a hearing for third parties and accept inter-employee disputes without upsetting the balance of interests among its members. It could follow precedents and render consistent interpretations, and it could decide all the cases on their merits. It could dispense with the present time-consuming practice of rearguing deadlocked cases before referees. The carrier members have always favored such a tribunal, but the labor members are opposed. ${ }^{109}$ One reason for their opposition is clear-under the present set-up, the unions they represent enjoy important advantages over competing unions. But the interest of railway labor as a whole must lie with an impartial administration of collective bargaining agreements rather than with a system which operates to the advantage of vested union interests. ${ }^{\text {xIo }}$ In the absence of such a sweeping legislative reform, the Supreme Court in the Slocum case would seem to have done collective bargaining in the railroad industry a distinct disservice.

\section{SPECIAL FINDINGS AND GENERAL VERDICTS THE RECONCILIATION DOCTRINE}

Legal philosophy has retreated from its former exaltation of trial by jury as the bulwark of Anglo-American jurisprudence ${ }^{x}$ to a new position, from

${ }^{308} \mathrm{~A}$ system of labor courts has been proposed, but their jurisdiction was to include compulsory arbitration of disputes over new contracts as well as enforcement of existing agreements. See Vickery, Labor Relations Law: The Ferguson-Smith Bill to Create Labor Courts, 33 A.B.A.J. 548 (1947).

${ }^{109}$ Jones, op. cit. supra note 37 , at II5.

${ }^{\text {Iro }}$ For contrary views see authority cited note 40 supra, at 9; Collective Bargaining, Grievance Adjustment, and the Rival Union, I7 Univ. Chi. L. Rev. 533 (1950).

The former authority suggests that effective majority rule may require that the interests of the majority govern the disposition of adjustments as well as the negotiation of new agreements. On this theory the man at the head of the seniority list would not be entitled to complain if removed, because his removal benefits all the employees below him on the list. It should be added that this authority also states the arguments against exclusive right in the bargaining agent to represent employees in adjustment proceedings, and makes no final choice between the two alternatives. In Elgin, J. \& E. R. Co. v. Burley, 325 U.S. FII (I945) the Supreme Court explicitly rejected the theory that the RLA conferred such an exclusive right on the elected bargaining agent.

I Note in this connection, the classic statement of Blackstone: "When the jury have delivered in their verdict, and it is recorded in court, they are then discharged. And so ends the trial by jury; which ever has been, and I trust ever will be, looked upon as the glory of the English law." $3 \mathrm{Bl}$. Comm. *378. 